\title{
ENGLISH TEACHER TEACHING STRATEGY AT SMAN 1 CIPATAT
}

\author{
Ai Siti Juariyah ${ }^{1}$, Siti Nurulika Gustira ${ }^{2}$, Evie Kareviati ${ }^{3}$ \\ ${ }^{1}$ IKIP Siliwangi \\ ${ }^{2}$ IKIP Siliwangi \\ ${ }^{3}$ IKIP Siliwangi \\ 1aisitijuariyah@yahoo.com, ${ }^{2}$ sgustira@yahoo.com ${ }^{3}$ akhmadjaelani91@yahoo.co.id
}

\begin{abstract}
Teaching strategy can describe effective teachers are always looking for something new to keep their students motivated and engaged. If you're as a new or experienced teacher, you will feel too much by all of the new educational buzzwords, theories, and new strategies that are out there. Strategy of teaching can be considered as something new that may not be suitable to be applied to your teaching style. In this teaching strategy, an English teacher observed used communicative approach and joyful learning approach. Teaching strategy is the most important to be existed and supported areas of in education field especially in a research. The research reviews concentrates to the whole literature includes research done is not educational settings or focuses on only a partial set of studies that may or may not be valid. There has never become a perfect research review on the achievement of the methods of teaching strategy used at many schools. An extensive search found at the school SMAN 1 Cipatat investigating a teaching method used. At the school, an English teacher observed had taught by communicative approach and joyful learning approach. The result of the teaching strategy used the teacher had a good effect on student achievement. When the effect of teaching strategy used by a teacher with the communicative and joyful learning approach, the strategy promoted the greatest effect namely the class atmosphere was life and interesting. The teacher's teaching performance was excellent.
\end{abstract}

Keywords: Communicative Approach, Joyful Learning Approach

\section{INTRODUCTION}

Learning process between teacher and student will be happened in learning activities. The process of learning activities can take place if there is cooperation between teachers and students in achieving learning objectives. Consequences in the implementation of learning should help students develop the potential students for environmental conditions.

To achieve these goals, it is necessary combination of learning variables such as teachers, student characteristics, learning methods, learning media and other supporting infrastructure.

In general, understanding analysis is the activity of thinking to describe a subject into parts or components in order to be known characteristics or signs of each part, then each other and the function of each section. 
The analysis is very important stage to do in a research to understand the data collected. Burns, (1994:287)stated that the purpose of analyzing the data is to find meaning in the data and this is done by systematically arranging and presenting the information. It has to be organized so that comparisons, contrasts and insight can be made and demonstrated. But the data is categorized not just to count occurrences. Instead, it is categorized to permit analysis and comparison of meaning within a category.

\section{Societal influences}

Teaching of language was originally considered as a cognitive matter, mainly involving memorization. It was considered on the later to be thought as socio-cognitive and it means that language can be learned from the social interaction process through communicative language teaching (CLT).

Chomsky, (1965:47) Focused on performance and competence in learning language and it was appeared to communicative language teaching, but as the conceptual idea for CLT was laid in the 1970s by linguists namely is Michael Alexander Kirkwood Halliday (British Linguist), who studied how language functions are expressed through grammar, and as an expert towards linguists, who introduced the idea of a larger communicative competence.

\section{Academic influences}

The CLT development was supported by new academic ideas. Before the growth happened to CLT, the earliest method of language teaching was based on being situational toward language teaching. This method was more clinical and need to be supported but it was less on direct communication.

\section{Classroom activities}

According to Richards, (2006:4-5)Teachers of CLT select classroom activities based on what they trust will be the most effective for students to develop their abilities in communicating in the target language. Oral activities are famous among CLT teachers, as disagree with some drills in learning grammar or writing and reading activities, because they contain conversation ability and creativity. The activities are different based on the language class level. They promote fluency, collaboration, and a pleasant feeling in the teaching language. Some activities are commonly used in CLT classrooms:

\section{Role-play}

Acording to Harmer, (1998:132) Role-play is a spoken activity usually accomplished between two persons to practice in improving their communicative abilities and it is usual accomplished for students in a certain setting.

Example:

1. The instructor arranges an area to do a conversation likes in a park, in a café, etc.)

2. The instructor explains the conversation aim for student's likes the speaker is ordering coffee, the speaker is talking about a movie they recently saw, the speaker is asking for directions, etc.) 
3. The students have a conversation with someone between two persons with amount of time prepared.

\section{Interviews}

According to Richards, (2006:34) Interview is a spoken activity accomplished between two persons to practice in improving their skills in the TL.

Example:

1. The instructor provides the same set of questions to each student to ask in a pair.

2. Students have a conversation by taking turns to ask and to answer the questions in pairs.

\section{Group work}

According to Harmer, (1998:131) Group work is an activity by collaborating whose target is to encourage communication in the TL, in a larger group setting.

Example:

1. Students are assigned a group of no more than six people.

2. Students are given work a specific acting within the group likes member A, member B.

3. The instructor provides each group in the same task to complete.

4. Every group member needs a planned amount of time to work on the part of the task to which they are chosen.

5. The group members talk about the information they have found, with each other and put it whole together to finish the task.

\section{Information gap}

According to Harmer, (1998:275) Information gap is an activity by collaborating whose target is for students in obtaining information effectively from something unknown until known in teaching language. Example:

1. The class is joined in a partner. One partner in each pair as Partner A, and the other as Partner B.

2. All students from Partner A are provided a paper sheet with a time-table on it. The timetable is completed in half-way, and some of the boxes are empty.

3. All students from Partner B are provided a paper sheet with a time-table on it. The empty boxes are on Partner A's time-table are completed on Partner B's. There are also empty boxes on Partner B's time-table, but they are completed on Partner A's.

4. The partners must collaborate in asking about and supplying each other with the information they are both missing, to complete each other's time-tables.

\section{Opinion sharing}

According to Richards, (2006:19) opinion sharing is a subject-based activity, whose target is to manage students' conversational skills, while talking about something topic.

Example: 


\section{Volume 1, No. 5, September 2018 pp 500-508}

1. The instructor introduces students a subject and requests them to consider their opinions about it such as dating, global warming, school dress codes.

2. The students discuss with each partner or small groups to debate their opinions on the topic.

\section{Critiques}

Although CLT has many influences in the field of language teaching, but universally it is not approved and has become a subject critique.

Swan, (1985:7) in his critique of CLT refers to the problem of theoretic and practice with CLT. He criticizes that CLT is not an altogether united subject, but one in which theoretical agreement (by linguists) and practical agreement (by language teachers) differ greatly. Critique of the theory of CLT contains that it creates broad claims about the usefulness of CLT while citing little data, that it uses a great amount of vocabulary makes confuse, and it thinks knowledge that is the most important of language non-specific likes the ability to create educated guesses. Swan gives suggestion that these theoretical issues can influence to confusion in the application of CLT techniques.

According to Elaine Ridge, (1992:65-75) writes that CLT possesses nonspecific requirements of its teachers, as there is no perfectly standard definition of what CLT is; this is especially true in grammar teaching (the formal rules influencing the standardized version of the language in question). Some critics toward CLT determine that the method does not judge enough emphasis on the grammar teaching and beside that it makes students to create utterances which are grammatically wrong as long as the interlocutor can get some meaning from them.

According to Bax, $(2003: 278)$ states that CLT has to accomplish with the context of its implementation. Bax states that many researchers connect the use of CLT techniques with modernity and, therefore, the lack of CLT techniques as a lack of modernism. In this way, these researchers think teachers or school systems which don't use CLT techniques as outdated and give suggestion that their students study the target language "in spite of" the absence of CLT techniques, as though CLT were the only way to study a language and everyone who fails to use its techniques is not having enough knowledge and its successful will not be achieved to teach the target language.

\section{How to Manage Your Class with Joyful Learning}

According to Regie Routman, (2015:1-12) by Middle Web. Published 09/01/2015. If you expect the most memorable learning experience from their students in some years after they have left a school, what would they say? Many students would be hard emphasize to remember even one academic learning event that can impact them in a positive way. In joyful learning, we are to be able to change for students, and for teachers too. Here's how.

\section{Make the challenge}

Start by managing minds and hearts in challenging subject matter and meaningful. If students care about the work and we give them excellent and sufficient resources, demonstrations, 
support and guidance, they will get advance as readers, writers, and thinkers and have good test scores too.

The work has to challenge and to be relevant based on the teaching and its evaluation as students' needs, culture, and interests.

\section{Frontload the learning challenge}

Frontloading contains everything we act before and during the learning process to ensure students can create their work successfully and as independently as possible. Frontloading may contain but is not limited to:
a. Immersion in a topic or genre (for example, through viewing, reading, examining, and/or listening to related texts, experts, videos)
b. Expressing and thinking aloud,
c. Shared experiences,
d. Questions that cause curiosity and deeper thinking and
e. The gathering and charting toward useful information.

\section{Become slower the teaching to get the learning quickly}

Get to learn deeply where students discuss, explore, and apply valuable concepts and problem solving strategies that transfer across disciplines.

Study locally likes threatened lake through finding information from some articles, books, websites, videos, field trips, Interviews with experts, the impact of farmers' use of pesticides, and deep talking about climate change, declining wetlands, crops and run off, and a heightened environmental awareness that led to actions on a crucial issue.

We can use some strategies to slow down learning as follows:

\section{Demonstrations}

Either we demonstrate the learner exactly what a "good one" looks like and sounds like or we describe the task or goal in a comprehensible way. We may think hard to write and read in front of our students, demonstrate revising process and our back and forth reasoning in reading and writing-including our struggle in giving examples and criteria of what the expectations are for.

\section{Shared Experiences}

In this stage of supporting student learners, we shall do the work together (all class or small group) while the teacher or expert takes the lead, often to think aloud while reading or composing. In reading step, students pay attention to a text to read aloud, and they must accomplish silently or orally. In writing step, students express freely about their ideas to collaborate on a text. The teacher gives confidence and accepts all student efforts and helps shape their language.

\section{Guiding and Practicing Independently.}

Create independent writing and independent reading - with sufficient election and valuable feedback built in - the number one priority and work backwards from there. Most important, if 
students aren't provided determined time every day to write and read meaningful texts, they won't get improvement much as readers and writers.

\section{Celebrate the Learning!}

Mention and write each learner's strengths and efforts. Such original celebration is at the heart of excellent teaching and leading. When feedback explicitly focuses first on what the learner is doing well before moving on to what may be necessary to get development for, students and teachers too to leave conversation, a conference, or task with the energy and will to "do the work," be part of a collaborative team, take risks, and develop the possibility expected.

\section{Famous joyful learning and teaching are the same everywhere}

About four decades working in usual schools in the U.S and Canada with great numbers of minority students and second language learners, over there have been got that one frequent is kids or teachers are the same. They are all eager to learn important things, and most are able to comprehend at high levels when we make the work interesting, relevant and doable and when we celebrate every learner's strengths and efforts.

\section{METHOD}

Researchers use qualitative research which is a research on descriptive research and tend to use analysis. Creswell, (2012:12-16) states that "qualitative research aims to explain the phenomenon in depth through the collection of data as deep as it is." Qualitative research emphasizes the depth of data obtained by researchers. The results of this study are subjective so that they can't be generalized. In general, qualitative research is done by interview and observation method. Through this method, researchers will analyze the data obtained from the field with details.

\section{RESULT AND DISCUSSION}

\section{Results}

Researchers analyze the English teaching and learning process at SMAN 1 Cipatat. Teachers teach with implementing a communicative learning teaching approach and joyful learning approach.

Based on some theories above researchers had got the result of research are as follow: Here, we are as researchers had finished a research. A teacher observed is Drs. Agus Sadikin, S.Pd. He is a teacher of English at SMAN 1 Cipatat. In his teaching methodology is very good, He used a communicative approach and joyful learning approach. He taught by using the two approaches uniquely. He has many skills in applying some good teaching strategies. He is very famous for his students. He could create a joyful learning to their students. He could accomplish his teaching process according to the instruction on how to teach well and perfectly. Some stages of his teaching process accomplished perfectly are as follow: 


\begin{tabular}{|c|c|c|}
\hline NO & ACTIVITIES & QUALITY \\
\hline $\mathbf{I}$ & PRE - LEARNING & \\
\hline 1 & Check the readiness of space, tools and learning media & Excellent \\
\hline 2 & Checking the students' readiness & Excellent \\
\hline II & OPENING LEARNING & \\
\hline 1 & Doing apperception activities & Excellent \\
\hline 2 & Convey the competence to be achieved and the plan of activities & Excellent \\
\hline III & WHILST LEARNING ACTIVITY & \\
\hline $\mathbf{A}$ & Learning material mastery & \\
\hline 1 & Correlating learning material with the relevant other knowledge & Excellent \\
\hline 2 & Correlating learning material with the real life & Excellent \\
\hline 3 & Achieving communicative goals & Excellent \\
\hline 4 & Using logical or rhetorical structure & Excellent \\
\hline 5 & Using linguistic elements & Excellent \\
\hline 6 & Using socio - cultural elements & Excellent \\
\hline B & Approach/Learning Strategy & \\
\hline 1 & Implementing learning based on the competence to be achieved & Excellent \\
\hline 2 & Implementing learning based on level of development of students need & Excellent \\
\hline 3 & Implementing a learning systematically & Excellent \\
\hline 4 & Class mastery & Excellent \\
\hline 5 & Implementing contextual learning & Excellent \\
\hline & Implementing learning that enables the growth of positive habits & Excellent \\
\hline 7 & Implementing learning according to the time allocated & Excellent \\
\hline 8 & Emphasizing the use of English as the language of instruction & Excellent \\
\hline 9 & $\begin{array}{l}\text { Emphasizing the fair and integrated use of listening, speaking, reading and writing } \\
\text { skills }\end{array}$ & Excellent \\
\hline $\mathbf{C}$ & Utilization of learning resources or learning media & \\
\hline 1 & Demonstrating skills in the use of learning resources or media & Excellent \\
\hline 2 & Producing an interesting message & Excellent \\
\hline 3 & $\begin{array}{l}\text { Involving students in the making and utilization of learning resources or learning } \\
\text { media }\end{array}$ & Excellent \\
\hline D & Learning that triggers and nurtures student involvement & \\
\hline 1 & Fostering students' active participation in learning & Excellent \\
\hline 2 & Respond positively to student participation & Excellent \\
\hline 3 & Facilitating teacher-student interaction & Excellent \\
\hline 4 & Showing a conducive interpersonal relationship & Excellent \\
\hline 5 & Fostering the cheerfulness and enthusiasm of students in learning & Excellent \\
\hline $\mathbf{E}$ & Process assessment and learning outcomes & \\
\hline 1 & Monitoring the progress of learning & Excellent \\
\hline 2 & Performing a final assessment in accordance with competence & Excellent \\
\hline IV & CLOSING & \\
\hline 1 & Reflecting or creating a summary by involving students & Excellent \\
\hline 2 & $\begin{array}{l}\text { Carrying out follow-up by providing direction, activities or duties as part of } \\
\text { remedial or enrichment }\end{array}$ & Excellent \\
\hline
\end{tabular}

\section{Discussion}

According to Harmer, (2007:52) Effective teachers are always move around to search something new and exciting teaching strategies that will insure their students motivated and engaged. He said that there are a few teaching strategies that have been a basic in most 
classrooms. They depend upon our style, preference, and our students, choose the ones that suite our needs. To implement the teaching strategies, teachers need to be prowl in improving their teaching performance. Practically, the English teacher at SMAN 1 Cipatat seem he needs to be stable in his teaching strategy because he almost perfectly in implementing his teaching strategies based on theoretically and practically even creatively.

As the last explanation above that Communicative language teaching (CLT) is an approach to language teaching that can emphasize interaction between the means and the ultimate target of study. Learners should talk about personal experiences with their partners, and instructors should teach subject outside of the area of traditional grammar, in order to develop language skills in all kinds of situations. This method also request to motivate learners to incorporate their personal experiences into their language learning environment, and to concentrate to the learning experience toward the learning of the target language. Where as Joyful learning approach is difficult to do by a teacher because many teachers will not have ability how to make joyful learning approach. Based on the view, the teachers should create their teaching style to make students to be interested to learn. In this research seems the English teacher at SMAN 1 Cipatat has had a talent in implementing communicative approach and joyful learning approach while the others may be difficult.

\section{CONCLUSION}

Teaching Strategy is a plan, method, or series of activities design to a certain educational goal. Therefore in this understanding, the teaching and learning strategy includes the plans, methods and learning techniques of the planned device of activities to achieve certain teaching objectives. To implement a particular strategy requires a set of teaching methods. Teaching strategy is defined as a plan of operation achieving something "activity plan to achieve something".

In teaching strategy will refer to the following questions : "How does a teacher apply the learning strategy?" As a prospective teacher, the researchers try to describe how to apply good teaching and learning strategies for the future so that our educational world has the potential of skilled human resources and able to compete with the outside world and raise the dignity of the nation, so that around the world is not only can say that our country is only rich in natural resources only.

In this case, the role of teachers to complete their calling duties is necessary. Teachers must have roles that can guide and support the mindset of learners to be achieving to expected learners such as, Constructive Teachers must always be innovative to adopt new methods to motivate learning of their students. He must place his students as learning centers, meaning that the material is not depended on the teacher and the curriculum but depends on the students.

A teacher is only a facilitator, motivator and inspirator of the teaching and learning process in the classroom, so that all the qualities of the students themselves will be appeared. All creativity has been lied within the children, because our children in the source of all its potentialities have a soul. Because of ignorance then we as a candidate / teacher is a spiritual guide to help provide knowledge to our students' soul. Involvement of the soul of a student in a teaching and learning activities, will provide a strong motivation to them. Our students will feel themselves worthy to do something that is impossible to be possible. So, the view is in accordance with Drs. Agus Sadikin, S.Pd that the teachers here should be "The Trigger for the Students Learning Process". 
Based on the background, researcher assumes necessary to know the teaching strategy used at SMAN 1 Cipatat. In its reality, the teacher used communicative approach and joyful learning approach. The result of the both approaches used by the teacher shows positive influence to his students in their classroom.

\section{REFERENCES}

Bax, S. (2003). The end of CLT: conntext approach to language teaching. ELT Journal, 53/3(The end of CLT: conntext approach to language teaching), 278-287.

Burns, R. B. (1994). Research Methode. Melbourne: Longman Australia.

Chomsky, N. (1965). ASPECTS OF T H E THEORY OF SYNTAX. Cambridge: THE M.I.T. PRESS.

Creswell, J. W. (2012). Educational Research: Planning, conducting and evaluating quantitative and qualitative research (4th ed.). Boston: Pearson Education.

Harmer, J. (1998). How to Teach. England: Pearson Education.

Richards, J. C. (2006). Communicative Language Teaching Today. Cambridge: Cambridge University Press. https://doi.org/10.1037/a0020992

Ridge, E. (1992). English Language Teaching in South Africa: Contributing To Equity in Education. English Language Teacing in Sout Africa: Contributing To Equity in Education, 65-75.

Routman, R. (2015). Creating a culture of health. Creating a Cultural of Health, 1-12.

Swan, M. (1985). A critical look at the communicative approach ELT, 39/1. 